\title{
Pedobacter composti sp. nov., isolated from compost
}

\author{
Correspondence \\ Sung-Taik Lee \\ e_stlee@kaist.ac.kr \\ Hee-Mock Oh \\ heemock@kribb.re.kr
}

\author{
Hyung-Gwan Lee, ${ }^{1}$ Song-Gun Kim, ${ }^{2}$ Wan-Taek $I m,{ }^{1}$ Hee-Mock $\mathrm{Oh}^{2}$ \\ and Sung-Taik Lee ${ }^{1}$
}
${ }^{1}$ Department of Biological Sciences, Korea Advanced Institute of Science and Technology, 373-1, Guseong-dong, Yuseong-gu, Daejeon 305-701, Republic of Korea
${ }^{2}$ Korean Collection for Type Cultures, Biological Resource Center, Korea Research Institute of Bioscience and Biotechnology, 52 Eoeun-dong, Yuseong-gu, Daejeon 305-806, Republic of Korea

\begin{abstract}
A Gram-negative, aerobic, rod-shaped, non-motile, non-spore-forming bacterial strain, designated TR6-06 ${ }^{\top}$, was isolated from a compost sample in South Korea and characterized taxonomically by using a polyphasic approach. The organism grew optimally at $30{ }^{\circ} \mathrm{C}$ and $\mathrm{pH}$ 6.5-7.0. The isolate was positive for catalase and oxidase tests, but negative for gelatinase and urease and for indole and $\mathrm{H}_{2} \mathrm{~S}$ production. Phylogenetic analyses based on 16S rRNA gene sequences revealed that strain TR6-06 ${ }^{\top}$ was most closely affiliated with members of the genus Pedobacter of the family Sphingobacteriaceae. Strain TR6 $-06^{\top}$ exhibited $16 \mathrm{~S}$ rRNA gene sequence similarity values of 89.9-93.5\% to the type strains of species of the genus Pedobacter. The $\mathrm{G}+\mathrm{C}$ content of the genomic DNA of strain TR6-06 ${ }^{\top}$ was $41.9 \mathrm{~mol} \%$. The predominant respiratory quinone was $M K-7$. The major fatty acids were iso- $\mathrm{C}_{15: 0}$, iso- $\mathrm{C}_{17: 0} 3-\mathrm{OH}, \mathrm{C}_{16: 1} \omega 7 \mathrm{c}$ and anteiso- $\mathrm{C}_{15: 0}$. These chemotaxonomic data support the affiliation of strain TR6-06 ${ }^{\top}$ to the genus Pedobacter. However, on the basis of its phenotypic properties and phylogenetic distinctiveness, strain TR6-06 ${ }^{\top}$ (=KCTC $12638^{\top}=$ LMG $23490^{\top}$ ) should be classified as the type strain of a novel species, for which the name Pedobacter composti sp. nov. is proposed.
\end{abstract}

The genus Pedobacter was proposed by Steyn et al. (1998) to accommodate species characterized by Gram-negative rods that produce heparinase, are obligately aerobic, with or without gliding motility, are negative for urease, lipase, gelatinase, arginine dihydrolase, indole production and nitrate reduction and contain iso- $\mathrm{C}_{15: 0}$, iso- $\mathrm{C}_{15: 0} 2-\mathrm{OH}$, iso- $\mathrm{C}_{15: 0} 3-\mathrm{OH}, \mathrm{C}_{16: 0}, \mathrm{C}_{16: 1} \omega 5 c, \mathrm{C}_{16: 1} \omega 7 c, \mathrm{C}_{16: 0} 3-\mathrm{OH}$, iso- $\mathrm{C}_{17: 0} 3-\mathrm{OH}$ and iso- $\mathrm{C}_{17: 1} \omega 9 c$ fatty acids. At the time of writing, the genus comprised 16 recognized species, including the recently described species Pedobacter lentus and Pedobacter terricola (Yoon et al., 2007). In this study, taxonomic characterization of a Pedobacter-like bacterial strain, TR6-06 ${ }^{\mathrm{T}}$, is reported.

Strain TR6-06 ${ }^{\mathrm{T}}$ was originally isolated from a compost sample composed of cow dung and rice straw near Daejeon city in South Korea. This compost sample was suspended in $50 \mathrm{mM}$ phosphate buffer ( $\mathrm{pH} 7.0)$ and the suspension was spread on R2A agar plates (Difco) after serial dilution

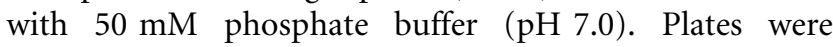
incubated at $30{ }^{\circ} \mathrm{C}$ for 2 weeks. Single colonies on these plates were purified by transferring them onto new plates and subjecting them to an additional incubation for 3 days

The GenBank/EMBL/DDBJ accession number for the 16S rRNA gene sequence of strain TR6-06 ${ }^{\top}$ is $A B 267720$. at $30{ }^{\circ} \mathrm{C}$. Purified colonies were tentatively identified using partial 16S rRNA gene sequences. Strain TR6-06 ${ }^{\mathrm{T}}$ was cultured routinely on $\mathrm{R} 2 \mathrm{~A}$ agar at $30{ }^{\circ} \mathrm{C}$ and maintained as a glycerol suspension $(20 \%, \mathrm{w} / \mathrm{v})$ at $-70{ }^{\circ} \mathrm{C}$.

The Gram reaction was performed by the non-staining method as described by Buck (1982). Cell morphology was observed at $1000 \times$ magnification with a light microscope (Nikon) using cells grown for 3 days at $30{ }^{\circ} \mathrm{C}$ on R2A agar. Motility was tested using the hanging drop technique. Catalase activity was determined by bubble production in $3 \%(\mathrm{v} / \mathrm{v}) \mathrm{H}_{2} \mathrm{O}_{2}$ and oxidase activity was determined using $1 \%(\mathrm{w} / \mathrm{v})$ tetramethyl $p$-phenylenediamine. Carbon source utilization and enzyme activities were tested by using the API 20E, API 20NE, API 32GN, API 50CH and API ZYM test kits (bioMérieux). Anaerobic growth was tested in serum bottles containing R2A broth supplemented with sodium thioglycollate $\left(1 \mathrm{~g} \mathrm{l}^{-1}\right)$ with the upper air layer substituted by nitrogen gas. Growth at different temperatures $\left(4,15,20,25,30,37\right.$ and $\left.42{ }^{\circ} \mathrm{C}\right)$ and $\mathrm{pH}(\mathrm{pH} 5.0-10.0$ at intervals of $0.5 \mathrm{pH}$ units) was assessed after 5 days incubation. Salt tolerance was determined on R2A agar supplemented with $1-10 \%(\mathrm{w} / \mathrm{v}) \mathrm{NaCl}$ after 5 days incubation. Growth on nutrient agar, trypticase soy agar (TSA) and MacConkey agar was also evaluated at $30{ }^{\circ} \mathrm{C}$. 
Cells of strain TR6-06 ${ }^{\mathrm{T}}$ were strictly aerobic, Gramnegative, non-motile, non-spore-forming and rod-shaped. Colonies grown on R2A agar plates for 4 days were $0.8-$ $1.5 \mathrm{~mm}$ in diameter. The isolate grew well on nutrient agar and TSA, but did not grow on MacConkey agar. Other physiological characteristics of strain TR6- $06^{\mathrm{T}}$ are sum- marized in the species description. Phenotypic characteristics that differentiate the novel isolate from its closest phylogenetic relatives are listed in Table 1 .

For measurement of the chromosomal DNA $\mathrm{G}+\mathrm{C}$ content, genomic DNA of the novel strain was extracted

Table 1. Comparison of the phenotypic characteristics of strain TR6-06 ${ }^{\top}$ and related type strains of species of the genus Pedobacter

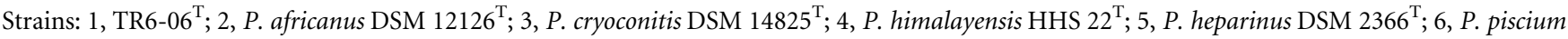
DSM $11725^{\mathrm{T}}$. All strains are positive for aerobic growth, catalase, oxidase, phosphatase, $\beta$-galactosidase, aesculin hydrolysis, and utilization of $N$ acetylglucosamine, maltose and salicin as sole carbon sources. All strains are negative for Gram staining, indole and $\mathrm{H}_{2} \mathrm{~S}$ production, urease, nitrate reduction to nitrite, utilization of inositol and L-histidine as sole carbon sources, and acid production from adonitol, D-lactose, melibiose and Drhamnose. +, Positive; -, negative; \pm , variable; NA, data not available. Data for taxa 2-6 are from Shivaji et al. (2005).

\begin{tabular}{|c|c|c|c|c|c|c|}
\hline Characteristic & 1 & 2 & 3 & 4 & 5 & 6 \\
\hline Habitat & Compost & Soil, sludge & $\begin{array}{l}\text { Glacier } \\
\text { cryoconite }\end{array}$ & Glacier water & Soil & Fish \\
\hline Colony diameter $(\mathrm{mm})$ & $0.8-1.5$ & $2-4$ & $1.6-2.0$ & $1.6-2$ & $1-4$ & $2-4$ \\
\hline Colony shape & $\begin{array}{l}\text { Round, convex, } \\
\text { smooth with } \\
\text { entire margins }\end{array}$ & $\begin{array}{l}\text { Round, convex, } \\
\text { smooth with } \\
\text { entire scalloped } \\
\text { margins }\end{array}$ & $\begin{array}{c}\text { Round, convex, } \\
\text { mucoid with } \\
\text { entire margins }\end{array}$ & $\begin{array}{c}\text { Round, convex, } \\
\text { mucoid with } \\
\text { entire margins }\end{array}$ & $\begin{array}{c}\text { Round, convex } \\
\text { or slightly } \\
\text { umbonate with } \\
\text { entire margins }\end{array}$ & $\begin{array}{c}\text { Round, convex, } \\
\text { opaque, } \\
\text { smooth with } \\
\text { entire margins }\end{array}$ \\
\hline Colony colour & Pale orange & $\begin{array}{c}\text { Translucent } \\
\text { yellow }\end{array}$ & $\begin{array}{l}\text { Creamish } \\
\text { white }\end{array}$ & Pale white & $\begin{array}{c}\text { Translucent } \\
\text { yellow }\end{array}$ & $\begin{array}{l}\text { Yellow or } \\
\text { creamish white }\end{array}$ \\
\hline Growth range $\left({ }^{\circ} \mathrm{C}\right)$ & $25-37$ & $\mathrm{NA}$ & $1-25$ & $4-25$ & $5-30$ & $5-30$ \\
\hline $\begin{array}{l}\text { Maximum growth temperature } \\
\left({ }^{\circ} \mathrm{C}\right)\end{array}$ & 37 & 37 & 25 & 25 & 37 & 30 \\
\hline Motility & Non-motile & Non-motile & Motile/gliding & Non-motile & Gliding & Non-motile \\
\hline Cell shape & Short rods & NA & Long rods & Long rods & Short rods & Long rods \\
\hline Gelatinase & - & \pm & + & + & - & - \\
\hline Lysine decarboxylase & - & + & - & - & + & + \\
\hline Tryptophan deaminase & - & - & - & + & - & NA \\
\hline Arginine dihydrolase & - & - & - & + & - & $\mathrm{NA}$ \\
\hline$\beta$-Glucosidase & + & \pm & + & + & - & + \\
\hline \multicolumn{7}{|l|}{ Acid production from: } \\
\hline D-Arabinose & - & \pm & - & - & \pm & \pm \\
\hline D-Glucose & - & + & - & - & + & + \\
\hline D-Mannose & - & - & - & + & - & NA \\
\hline Mannitol & - & - & + & + & - & \pm \\
\hline Inositol & - & - & - & + & - & - \\
\hline Sorbitol & - & - & - & + & - & - \\
\hline \multicolumn{7}{|l|}{ Utilization of carbon sources: } \\
\hline D-Arabinose & + & \pm & - & + & - & - \\
\hline Ribose & - & \pm & - & + & - & - \\
\hline D-Glucose & + & - & + & + & - & - \\
\hline L-Fucose & - & \pm & + & + & + & - \\
\hline L-Rhamnose & - & + & - & + & + & \pm \\
\hline Melibiose & - & + & + & + & + & + \\
\hline Sucrose & - & + & + & + & + & + \\
\hline Glycogen & - & - & + & - & - & - \\
\hline Mannitol & - & - & - & + & + & - \\
\hline D-Sorbitol & - & - & - & + & + & - \\
\hline L-Alanine & - & \pm & - & + & - & - \\
\hline L-Serine & - & + & - & + & \pm & \pm \\
\hline L-Proline & - & \pm & - & + & - & + \\
\hline DNA G $+\mathrm{C}$ content $(\mathrm{mol} \%)$ & 42 & $43-45$ & 43 & 41 & $42-43$ & $40-43$ \\
\hline
\end{tabular}


and purified as described by Moore \& Dowhan (1995) and degraded enzymically into nucleosides; $\mathrm{G}+\mathrm{C}$ content was determined as described by Mesbah et al. (1989) using reverse-phase HPLC. Isoprenoid quinones were extracted with chloroform/methanol $(2: 1, \mathrm{v} / \mathrm{v})$, evaporated under vacuum conditions and re-extracted in $n$-hexane/water $(1: 1, \mathrm{v} / \mathrm{v})$. The crude $\mathrm{n}$-hexane/quinone solution was purified using Sep-Pak Vac silica cartridges (Waters) and then analysed by HPLC, as described previously (Hiraishi et al., 1996). Cellular fatty acid profiles were determined for strains grown on TSA (Difco) for 3 days. The cellular fatty acids were saponified, methylated and extracted according to the protocol of the Sherlock Microbial Identification System (MIDI). The fatty acids analysed by GC (Hewlett Packard 6890) were identified by the Microbial Identification software package (Sasser, 1990).

The $\mathrm{G}+\mathrm{C}$ content of genomic DNA of strain TR6- $06^{\mathrm{T}}$ was $41.9 \mathrm{~mol} \%$. The predominant menaquinone was MK-7. The fatty acid profile of strain TR6- $06^{\mathrm{T}}$ was composed of branched-chain, saturated and unsaturated fatty acids; the major fatty acids were iso- $\mathrm{C}_{15: 0}(31.7 \%)$, anteiso- $\mathrm{C}_{15: 0}$ (8.9\%), iso- $\mathrm{C}_{17: 0} 3-\mathrm{OH}(12.5 \%)$ and $\mathrm{C}_{16: 1} \omega 7 c(11.8 \%)$. Fatty acid data for strain TR6- $06^{\mathrm{T}}$ and related type strains of Pedobacter species are given in Table 2 . The fatty acid profile of strain TR6- $06^{\mathrm{T}}$, including iso- $\mathrm{C}_{15: 0}$, iso- $\mathrm{C}_{17: 0}$

Table 2. Fatty acid composition (\%) of strain TR6- $06^{\top}$ and related type strains of species of the genus Pedobacter

Strains: 1 , TR6- $06^{\mathrm{T}} ; 2$, P. africanus DSM $12126^{\mathrm{T}} ; 3$, P. cryoconitis DSM $14825^{\mathrm{T}} ; 4$, P. himalayensis HHS $22^{\mathrm{T}} ; 5$, P. heparinus DSM $2366^{\mathrm{T}} ; 6, P$. piscium DSM $11725^{\mathrm{T}}$. Strain TR6- $06^{\mathrm{T}}$ was grown in TSA medium at $30{ }^{\circ} \mathrm{C}$ for the determination of fatty acid composition in the present study. Data for taxa 2-6 are from Shivaji et al. (2005). tr, Trace $(<1 \%) ;-$, not detected; ECL, equivalent chain-length.

\begin{tabular}{|c|c|c|c|c|c|c|}
\hline Fatty acid & 1 & 2 & 3 & 4 & 5 & 6 \\
\hline ECL 13.566 & 1.3 & 2.6 & - & - & 5.0 & $\operatorname{tr}$ \\
\hline $\mathrm{C}_{14: 0}$ & $\operatorname{tr}$ & 1.5 & 1.0 & 1.0 & 1.1 & 1.3 \\
\hline $\mathrm{C}_{15: 0}$ & 6.0 & $\operatorname{tr}$ & 2.0 & 2.0 & 1.1 & 2.0 \\
\hline $\mathrm{C}_{15: 1} \omega 6 c$ & 3.8 & $\operatorname{tr}$ & 2.0 & 2.0 & 2.0 & 2.0 \\
\hline iso- $\mathrm{C}_{15: 0}$ & 31.7 & 26.6 & 15.0 & 33.0 & 28.2 & 26.2 \\
\hline anteiso- $\mathrm{C}_{15: 0}$ & 8.9 & $\operatorname{tr}$ & 2.0 & 2.0 & $\operatorname{tr}$ & 2.6 \\
\hline iso- $\mathrm{C}_{15: 0} 2-\mathrm{OH}$ & - & 1.0 & 2.0 & 2.0 & 1.0 & 1.1 \\
\hline iso- $\mathrm{C}_{15: 0} 3-\mathrm{OH}$ & 5.2 & 2.1 & 1.9 & 1.5 & 2.5 & 2.5 \\
\hline $\mathrm{C}_{16: 0}$ & 2.8 & 3.8 & 9.1 & 7.3 & 3.0 & 3.3 \\
\hline $\mathrm{C}_{16: 1} \omega 5 c$ & $\operatorname{tr}$ & 2.1 & 2.0 & 2.0 & 1.4 & 3.5 \\
\hline $\mathrm{C}_{16: 1} \omega 7 c$ & 11.8 & 23.7 & 27 & 20.0 & 20.2 & 31.4 \\
\hline $\mathrm{C}_{16: 0} 3-\mathrm{OH}$ & 1.1 & 3.1 & 2.0 & 2.0 & 1.5 & 4.5 \\
\hline iso- $\mathrm{C}_{16: 0} 3-\mathrm{OH}$ & 3.6 & $\operatorname{tr}$ & $\operatorname{tr}$ & $\operatorname{tr}$ & $\operatorname{tr}$ & $\operatorname{tr}$ \\
\hline iso- $\mathrm{C}_{16: 1} \mathrm{OH}$ & 1.9 & - & - & - & - & - \\
\hline $\mathrm{C}_{16: 0}$ 10-methyl & 2.1 & - & - & - & - & - \\
\hline ECL 16.580 & $\operatorname{tr}$ & 1.0 & 2.0 & 2.0 & 1.0 & $\operatorname{tr}$ \\
\hline iso- $\mathrm{C}_{17: 1} \omega 9 c$ & - & 4.4 & 8.6 & 4.0 & 6.3 & 1.6 \\
\hline anteiso- $\mathrm{C}_{17: 1} \omega 9 c$ & 1.5 & 2.0 & 2.0 & 2.0 & 2.0 & 1.2 \\
\hline iso- $\mathrm{C}_{17: 0} 3-\mathrm{OH}$ & 12.5 & 14.7 & 4.2 & 6.0 & 15.2 & 9.2 \\
\hline
\end{tabular}

3- $\mathrm{OH}$ and $\mathrm{C}_{16: 1} \omega 7 c$ as the major fatty acids, is similar to those of species of the genus Pedobacter, although there are differences in the proportions of some fatty acids, perhaps because of differences in extraction and cultivation conditions (Shivaji et al., 2005; Vanparys et al., 2005; Ten et al., 2006).

Extraction of genomic DNA, PCR-mediated amplification of the 16S rRNA gene and sequencing of the purified PCR product were carried out according to Kim et al. (2005). Full sequences of the 16S rRNA gene were compiled using SEQMAN software (DNASTAR). The 16S rRNA gene sequences of related taxa were obtained from GenBank. Multiple alignments were performed with the program CLUSTAL_X (Thompson et al., 1997). Gaps were edited in the program BIOEDIT (Hall, 1999). Evolutionary distances were calculated using the Kimura two-parameter model (Kimura, 1983). Phylogenetic trees were constructed by using the neighbour-joining method (Saitou \& Nei, 1987) with the MEGA3 program (Kumar et al., 2004) with bootstrap values based on 1000 replications (Felsenstein, 1985).

Nearly complete $16 \mathrm{~S}$ rRNA gene sequences (1430 bp) of strain TR6- $06^{\mathrm{T}}$ were determined and subjected to phylogenetic analysis; results indicated that strain TR6-06 ${ }^{\mathrm{T}}$ belonged to the genus Pedobacter (Fig. 1). Strain TR6-06 ${ }^{\mathrm{T}}$ showed the highest level of $16 \mathrm{~S}$ rRNA gene sequence similarity to Pedobacter africanus DSM $12126^{\mathrm{T}}$ (93.3\% similarity), followed by Pedobacter cryoconitis DSM $14825^{\mathrm{T}}$ (93.1\%), Pedobacter himalayensis HHS $22^{\mathrm{T}}$ (93.0\%), Pedobacter heparinus DSM $2366^{\mathrm{T}}(92.6 \%)$ and Pedobacter piscium DSM $11725^{\mathrm{T}}(92.5 \%)$. The values $(<97 \%)$ were low enough, according to Stackebrandt \& Goebel (1994), to classify strain TR6- $06^{\mathrm{T}}$ as a representative of a novel species in the genus Pedobacter.

On the basis of the data described above, strain TR6- $06^{\mathrm{T}}$ should be assigned to the genus Pedobacter as the type strain of a novel species, for which the name Pedobacter composti sp. nov. is proposed.

\section{Description of Pedobacter composti sp. nov.}

Pedobacter composti (com.pos'ti. N.L. gen. n. composti of compost).

Cells are Gram-negative, strictly aerobic, non-motile and $0.2-0.3 \times 1.2-1.6 \mu \mathrm{m}$ after cultivation for 4 days on R2A agar. Colonies grown on R2A agar (Difco) for 3 days are smooth, circular, convex and pale orange in colour. Good growth occurs at $30{ }^{\circ} \mathrm{C}$ and $\mathrm{pH}$ 7.0. Growth is observed at $15-37{ }^{\circ} \mathrm{C}$, at $\mathrm{pH} 5.0-8.0$ and in $0-1 \%$ (w/v) NaCl. Unable to reduce nitrate. Anaerobic growth does not occur. Substrate utilization, enzyme production and other physiological characteristics are indicated in Table 1. In addition, utilizes L-arabinose, glucose, maltose, mannose, $\mathrm{N}$-acetylglucosamine and salicin as sole carbon sources. Does not utilize acetate, adipate, L-alanine, caprate, citrate, L-fucose, gluconate, glycogen, L-histidine, 3- or 4-hydroxybenzoate, 3-hydroxybutyrate, inositol, itaconate, 2- or 


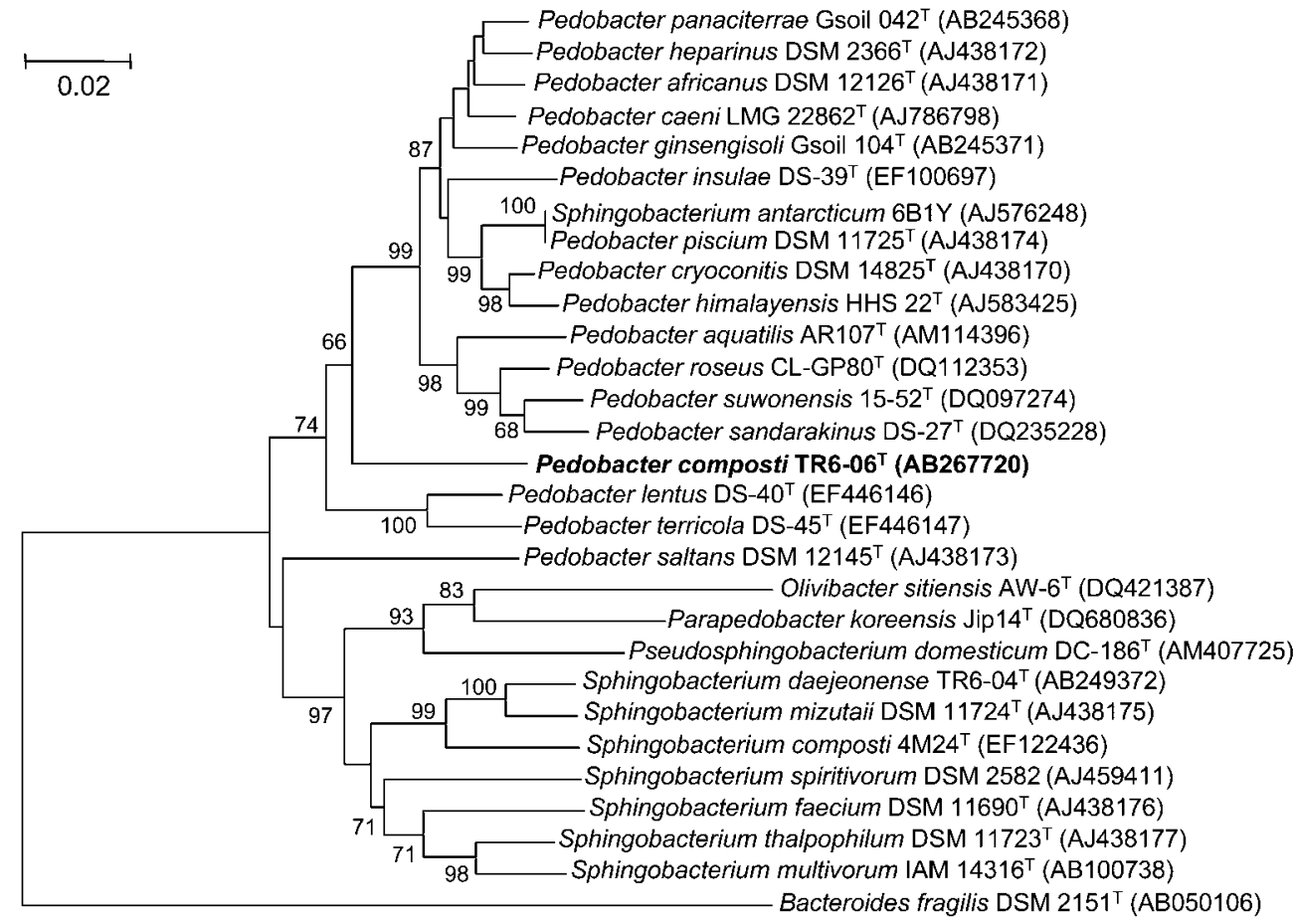

Fig. 1. Phylogenetic tree constructed from a comparative analysis of $16 \mathrm{~S}$ rRNA gene sequences showing the relationship between Pedobacter composti TR6-06 ${ }^{\top}$ and related species. The tree was constructed using the neighbour-joining method (Saitou \& Nei, 1987) with a two-parameter distance matrix (Kimura, 1983) and pairwise deletion. Bootstrap values (expressed as percentages of 1000 replications) greater than $60 \%$ are shown at the branch points. Bar, 0.02 substitutions per nucleotide position.

5-ketogluconate, lactate, malate, malonate, mannitol, melibiose, phenylacetate, L-proline, propionate, rhamnose, ribose, L-serine, sorbitol, suberate, sucrose or valerate as sole carbon sources. In API $50 \mathrm{CH}$ tests, acid is produced only from aesculin; acid is not produced from $\mathrm{N}$ acetylglucosamine, adonitol, amygdalin, D- or L-arabinose, D- or L-arabitol, arbutin, cellobiose, dulcitol, erythritol, Dor L-fucose, fructose, galactose, gentiobiose, glucose, gluconate, glycerol, glycogen, inositol, inulin, 2- or 5ketogluconate, lactose, D-lyxose, maltose, mannitol, mannose, melibiose, melezitose, methyl $\alpha$-D-glucoside, methyl $\alpha$-D-mannoside, methyl $\beta$-D-xyloside, raffinose, rhamnose, ribose, salicin, sorbitol, sorbose, starch, sucrose, D-tagatose, trehalose, turanose or D- or L-xylose. According to the API ZYM gallery, positive for acid phosphatase, alkaline phosphatase, cystine arylamidase, esterase (C4), esterase lipase (C8), leucine arylamidase, $N$-acetyl- $\beta$-glucosaminidase, valine arylamidase, $\beta$-galactosidase and $\beta$-glucosidase, weakly positive for $\alpha$-glucosidase, and tests negative for lipase (C14), naphthol-AS-BI-phosphohydrolase, trypsin, $\alpha$-chymotrypsin, $\alpha$-fucosidase, $\alpha$-galactosidase, $\alpha$-mannosidase and $\beta$-glucuronidase. The predominant menaquinone is MK-7. The major fatty acids are iso- $\mathrm{C}_{15: 0}$, iso- $\mathrm{C}_{17: 0} 3-$ $\mathrm{OH}, \quad \mathrm{C}_{16: 1} \omega 7 c$ and anteiso- $\mathrm{C}_{15: 0}$. Other phenotypic characteristics are given in Table 1.
The type strain, TR6- $06^{\mathrm{T}}\left(=\right.$ KCTC $\left.12638^{\mathrm{T}}=\mathrm{LMG} 23490^{\mathrm{T}}\right)$, was isolated from compost near Daejeon city, South Korea. The genomic DNA G+C content of the type strain is $41.9 \mathrm{~mol} \%$.

\section{Acknowledgements}

This work was supported by the 21C Frontier Microbial Genomics and Applications Center Program, Ministry of Education, Science and Technology, Republic of Korea.

\section{References}

Buck, J. D. (1982). Nonstaining (KOH) method for determination of Gram reactions of marine bacteria. Appl Environ Microbiol 44, 992993.

Felsenstein, J. (1985). Confidence limits on phylogenies: an approach using the bootstrap. Evolution 39, 783-791.

Hall, T. A. (1999). BioEdit: a user-friendly biological sequence alignment editor and analysis program for Windows 95/98/NT. Nucleic Acids Symp Ser 41, 95-98.

Hiraishi, A., Ueda, Y., Ishihara, J. \& Mori, T. (1996). Comparative lipoquinone analysis of influent sewage and activated sludge by high-performance liquid chromatography and photodiode array detection. J Gen Appl Microbiol 42, 457-469. 
Kim, M. K., Im, W.-T., Ohta, H., Lee, M. \& Lee, S.-T. (2005). Sphingopyxis granuli sp. nov., a $\beta$-glucosidase-producing bacterium in the family Sphingomonadaceae in $\alpha-4$ subclass of the Proteobacteria. J Microbiol 43, 152-157.

Kimura, M. (1983). The Neutral Theory of Molecular Evolution. Cambridge: Cambridge University Press.

Kumar, S., Tamura, K. \& Nei, M. (2004). MEGA3: integrated software for Molecular Evolutionary Genetics Analysis and sequence alignment. Brief Bioinform 5, 150-163.

Mesbah, M., Premachandran, U. \& Whitman, W. B. (1989). Precise measurement of the $\mathrm{G}+\mathrm{C}$ content of deoxyribonucleic acid by highperformance liquid chromatography. Int J Syst Bacteriol 39, 159-167.

Moore, D. D. \& Dowhan, D. (1995). Preparation and analysis of DNA. In Current Protocols in Molecular Biology, pp. 2-11. Edited by F. M. Ausubel, R. Brent, R. E. Kingston, D. D. Moore, J. G. Seidman, J. A. Smith \& K. Struhl. New York: Wiley.

Saitou, N. \& Nei, M. (1987). The neighbor-joining method: a new method for reconstructing phylogenetic trees. Mol Biol Evol 4, 406-425.

Sasser, M. (1990). Identification of bacteria by gas chromatography of cellular fatty acids, MIDI Technical Note 101. Newark, DE: MIDI Inc.

Shivaji, S., Chaturvedi, P., Reddy, G. S. N. \& Suresh, K. (2005). Pedobacter himalayensis sp. nov., from the Hamta glacier located in the Himalayan mountain ranges of India. Int J Syst Evol Microbiol 55, 1083-1088.
Stackebrandt, E. \& Goebel, B. M. (1994). Taxonomic note: a place for DNA-DNA reassociation and $16 \mathrm{~S}$ rRNA sequence analysis in the present species definition in bacteriology. Int J Syst Bacteriol 44, 846849.

Steyn, P. L., Segers, P., Vancanneyt, M., Sandra, P., Kersters, K. \& Joubert, J. J. (1998). Classification of heparinolytic bacteria into a new genus, Pedobacter, comprising four species: Pedobacter heparinus comb. nov., Pedobacter piscium comb. nov., Pedobacter africanus sp. nov. and Pedobacter saltans sp. nov. Proposal of the family Sphingobacteriaceae fam. nov. Int J Syst Bacteriol 48, 165-177.

Ten, L. N., Liu, Q.-M., Im, W.-T., Lee, M., Yang, D.-C. \& Lee, S.-T. (2006). Pedobacter ginsengisoli sp. nov., a novel DNase-producing bacterium isolated from soil of a ginseng field in South Korea. Int $J$ Syst Evol Microbiol 56, 2565-2570.

Thompson, J. D., Gibson, T. J., Plewniak, F., Jeanmougin, F. \& Higgins, D. G. (1997). The CLUSTAL_X windows interface: flexible strategies for multiple sequence alignment aided by quality analysis tools. Nucleic Acids Res 25, 4876-4882.

Vanparys, B., Heylen, K., Lebbe, L. \& De Vos, P. (2005). Pedobacter caeni sp. nov., a novel species isolated from a nitrifying inoculum. Int J Syst Evol Microbiol 55, 1315-1318.

Yoon, J.-H., Kang, S.-J., Park, S. \& Oh, T.-K. (2007). Pedobacter lentus sp. nov. and Pedobacter terricola sp. nov., isolated from soil. Int J Syst Evol Microbiol 57, 2089-2095. 